
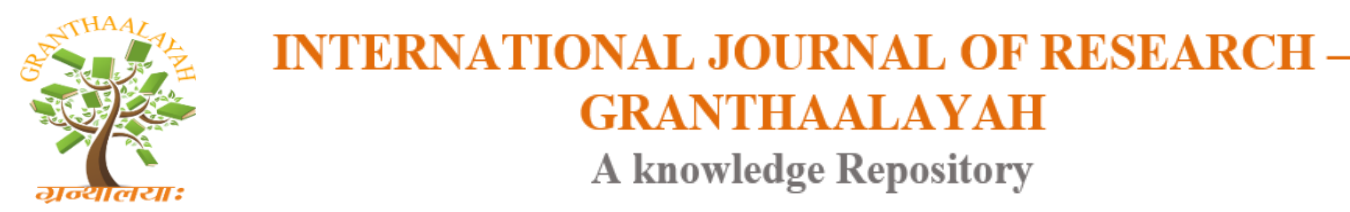

Science

\title{
HYDROGEOLOGICAL WINDOWS IN THE UPPER AQUIFER OF THE CHAD FORMATION IN THE CHAD BASIN, NORTH-EASTERN NIGERIA
}

\author{
S. Adamu ${ }^{1}$, M. Bukar ${ }^{* 1}$, H. M. Sadiq ${ }^{1}$ \\ ${ }^{1}$ Department of Geology, University of Maiduguri, Nigeria
}

\begin{abstract}
Groundwater is the major source of drinking water in both urban and rural communities around Chad Basin in Northeastern Nigeria. Besides, it is an important source of water for the agricultural and the industrial sector. In this work, hydrogeological windows of the Upper aquifer subzones of the Chad Basin around Bornu sub-basin have been studied. The research involves collection of borehole logs from Borno State Water Board in which the position of each borehole located on a topographic map at scale of 1:500,000. The thicknesses of Upper aquifer subzones at different locations were screened with the top and bottom bed values subtracted from their elevations. Contours of each corresponding values were drawn and contours of recharge windows were demarcated. The results showed that the upper aquifer is divided into ' $a$ ', ' $b$ ' and 'c' subzones. It also revealed detailed structural behavior of hydrogeological openings that enable the penetration of water from the surface to the three subzones of the Upper aquifer through hydrogeological windows and vice versa. The upper a-subzone is connected to lower upper c-subzone in the upper aquifer that subsequently permit flow of water to the Middle aquifer. These hydrogeological windows are mostly located around Bama, Maiduguri, Damaturu, Monguno, Damasack, Ngala and Kala-Balge. Conclusively, these windows are conduits of recharge into to the upper zones and infiltrate to the Upper b-subzone of the middle aquifer and contribute to balance abstracted water in middle aquifer for economic purposes.
\end{abstract}

Keywords: Upper Aquifer; Chad Formation; Contours; Recharge; Hydrogeological Windows.

Cite This Article: S. Adamu, M. Bukar, and H. M. Sadiq. (2018). "HYDROGEOLOGICAL WINDOWS IN THE UPPER AQUIFER OF THE CHAD FORMATION IN THE CHAD BASIN, NORTH-EASTERN NIGERIA." International Journal of Research Granthaalayah, 6(3), 30-38. https://doi.org/10.29121/granthaalayah.v6.i3.2018.1495.

\section{Introduction}

The Chad Basin with an area of about 2,335,000 $\mathrm{km}^{2}$ occupies a vast area with an altitude between $200 \mathrm{~m}$ and $500 \mathrm{~m}$ above sea level in Central Africa [1-3]. The Borno Basin (Nigerian sector of the Chad Basin) occupies approximately 10 percent of the Chad Basin and lies between latitude $11^{0} 25^{\prime} \mathrm{N}$ to $13^{0} 30^{\prime} \mathrm{N}$ and longitudes $11^{0} 35^{\prime} \mathrm{E}$ to $14^{0} 35^{\prime} \mathrm{E}$ [3]. 
The tectonic evolution of the Chad Basin can be traced back to the origin of the basin; it is a large structural depression that lies within the border margin of five contiguous countries: Nigeria, Chad, Niger Republic, Central African Republic and Cameroon Republic. The basin belongs to a series of rift System and later rift Basins in Central and West Africa (Fig. 1). The origin of the Basin is generally attributed to the rift system that developed in the early rift System period when the African - Southern American lithospheric plates separated and the Atlantic Ocean opened (Fig. 1). The sediments of Chad Formation in Bornu Basin are generally horizontal with a slight northeast dip in the direction of Lake Chad with maximum dip angle of 5 $-10^{0}$ as measured on outcropping beds along River Ngadda. The tectonic frame work and evolution of the Borno Basin (southern part of Chad Basin) took place during the evolution of the West African Rift System Basin leading to sedimentation in the Basin and deposition of Chad Formation as the youngest stratigraphic formation in the Borno Basin [4]. These evolution and sedimentation activities in the Basin attracted the attention of many workers [5- 12]. The most recent work on the structures of the basin showing an Isobaths map of the basement which revealed the sedimentary column in Borno basin with maximum thickness of about $6000 \mathrm{~m}$ within Maiduguri Sub-basin. Hydrogeologically important is the Chad Formation which contained three sandy horizons separated by thick clays referred to as 'Upper, Middle and Lower' aquifers. The recharge routes of the different aquifers in this sub-basin have not been clearly understood. This work intends to produce elevation maps showing the upper and lower elevations of the different aquifer subzones and demarcate the hydrogeological windows of the different zones of the aquifer.

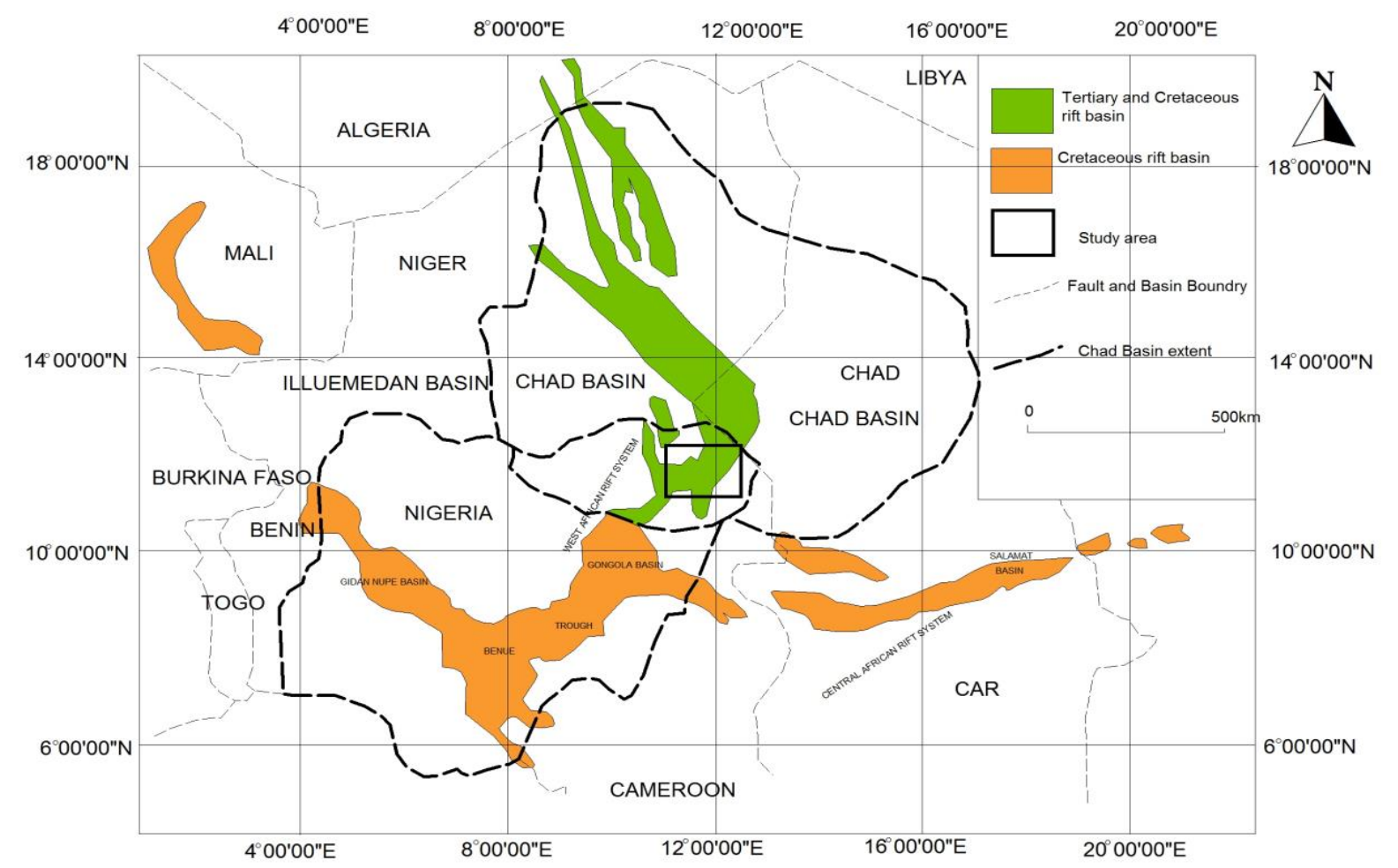

Figure 1: Location map of Borno Basin within regional setting of West and Central African Rift System (after Genik, 1992) 


\section{Materials and Method}

The study involved collection of relevant published and unpublished data, borehole logs and Topographic map of the study area, (Sheet 4 on a scale of 1:500,000. The map was used as a base map for location of boreholes and construction of the structural map. Satellite navigator (GPS) and other field materials were also used for accurate documentation of locations and elevations. Eighty boreholes were identified and mapped on the field and their logs collected from Borno State water board Maiduguri and Yobe State water board for this study (Fig. 2). Hydrogeological cross-sections along the boreholes were drawn to study various Chad Formation units at subsurface. For the construction of the structural map, a cross-section along A-B and C-D were constructed from values of the top and bottom of lithological logs. The values were subtracted from the values of elevation of each borehole and contour lines were drawn at selected contour intervals of 0, 50,100, 150, 200, 250, 300 and 350. A perpendicular line A-B and horizontal line C-D were drawn. The beginning and the end of the lines of cross-section were indicated on a plane sheet, after which the plane sheet were placed on the cross-section profiles on all the maps to mark out each contour value on the sheet. The contour values were used to graduate a vertical axis while the horizontal axis was drawn using line of the crosssection, on another plane sheet. Points of contour values were marked out from the vertical axis and finally hydrogeological cross-section were drawn across profiles A-B and C-D where equal lithologic logs were interpreted.

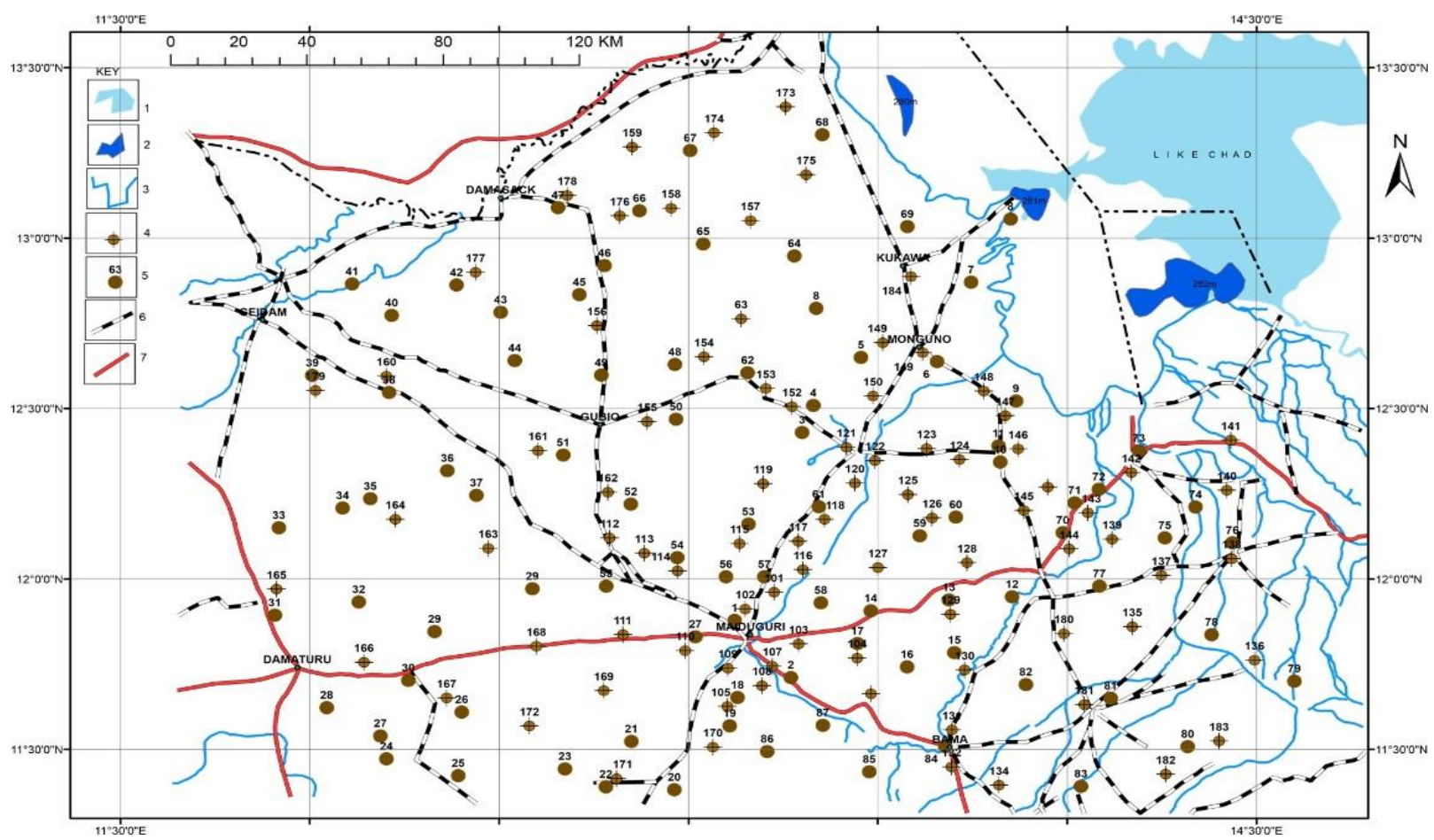

Figure 2: Location map of the study area showing the distribution of the studied hand dug wells and boreholes

Explanation; 1-Lake Chad in 1953 impenetrable surface in white and open water surface in light blue; 2-Remnants of Lake Chad in 2011 in dark blue from Google Earth; 3-Rivers Channels; 4-

Borehole; 5- Hand dug wells; 6-Minor Road; 7-Major Road. 


\section{Results and Discussion}

From the results it can be interpreted that, the Upper zone of the Chad Formation consist of a subzones, b-subzones and c-subzone which was mentioned [13] but could not provide structural evidence of the Upper a-subzone, b-subzone and c-subzone as presented in this work (Fig. 3). From these three subzones, the borehole logs of the top and bottom of the subzones studied revealed pinching of the bed as a result of erosions that wash sedimentary layers out before subsequent sedimentations. These pinch-outs provide a hydrogeological window for the migration of water from the surface during rainfall to the subzones (Fig. 4 to 8) around Damaturu, Maiduguri, Gubio, Monguno, Bama, Damasack and extended to Dikwa, Ngala and Kala Balge.

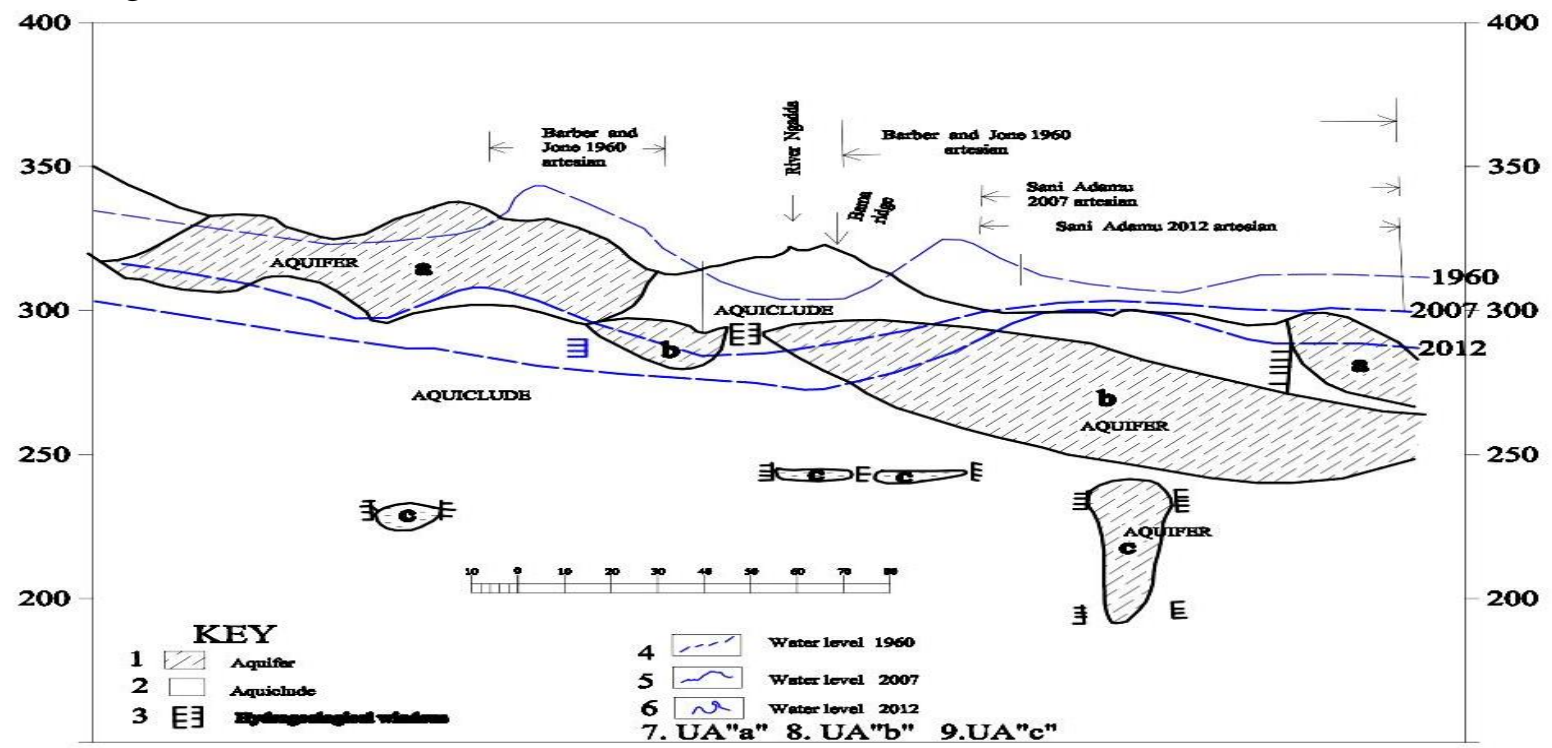

Figure 3: Map of hydrogeological cross-section C-D of Chad Formation showing detailed structural map of Upper Aquifer (UA) and piezometric level tapping Middle and Lower Aquifer

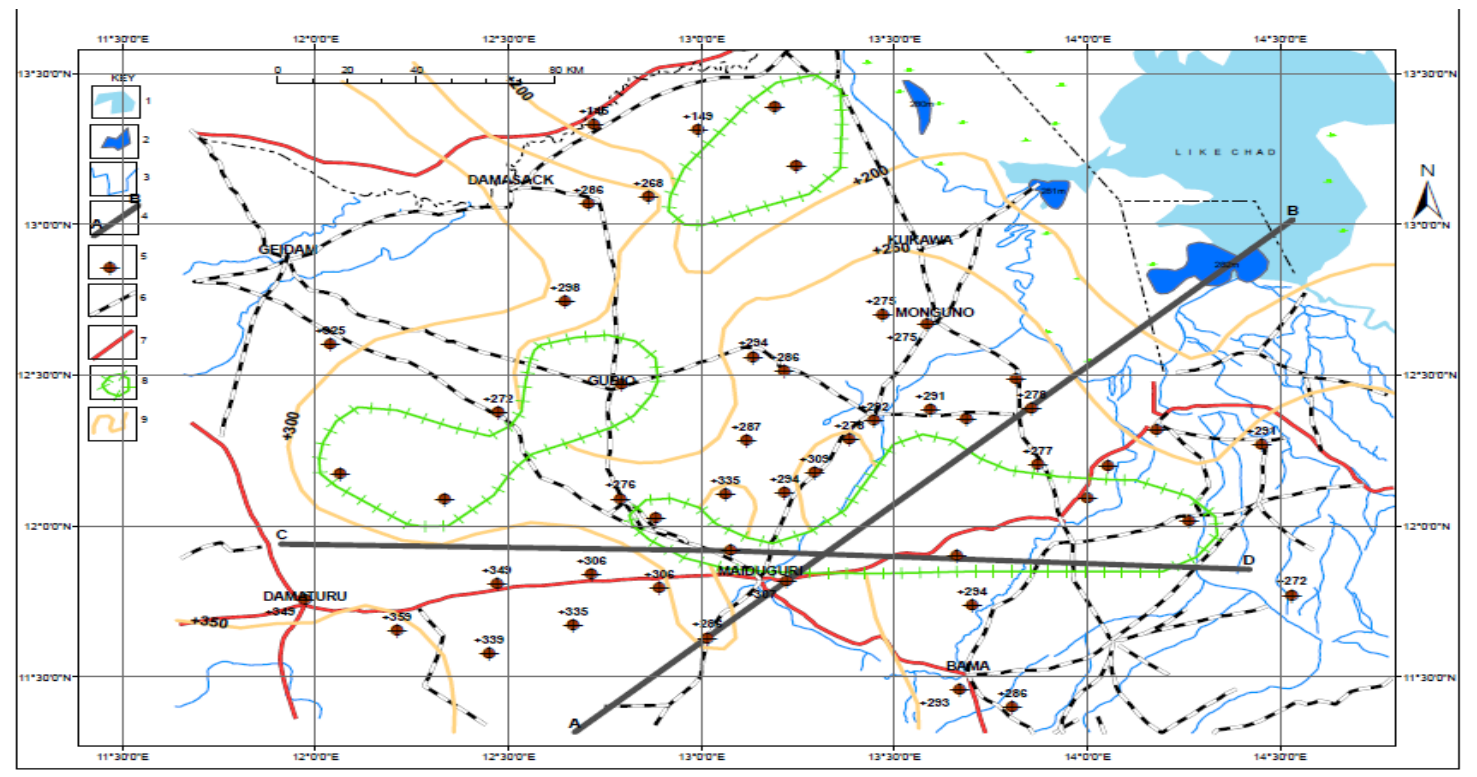

Figure 4: Map of Elevation of bottom of Upper Aquifer 'a' sub-zones 
Explanation; 1-Lake Chad in 1953 impenetrable surface in white and open water surface in light blue; 2-Remnants of Lake Chad in 2011 in dark blue from Google Earth; 3-Rivers Channels; 4Cross section along AB and CD; 5-Borehole; 6-Minor Road; 7-Major Road; 8-Boundaries of Hydrogeological windows in the Upper Aquifer 'a' sub-zone; 9 -Contours of bottom of Upper 'a' sub-zone

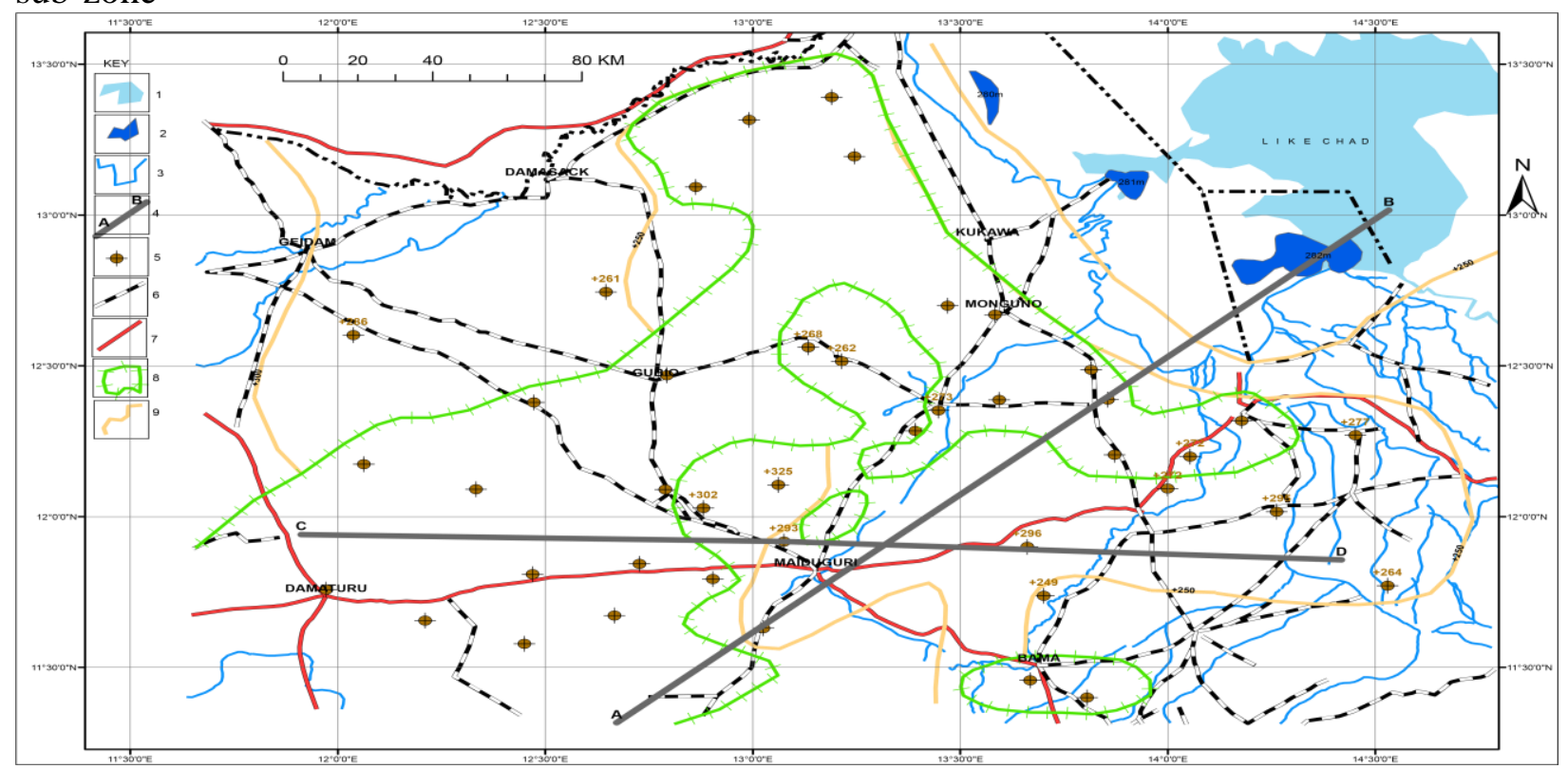

Figure 5: Map of Elevation of Top of the Upper Aquifer ' b' sub-zones. Explanation; 1-Lake

Chad in 1953 impenetrable surface in white and open water surface in light blue; 2-Remnants of Lake Chad in 2011 in dark blue from Google Earth; 3-Rivers Channels; 4- Cross section along $\mathrm{AB}$ and $\mathrm{CD}$; 5-Borehole; 6-Minor Road; 7-Major Road; 8-Boundaries of Hydrogeological windows in the Upper Aquifer 'b' sub-zone; 9-Contours of bottom of Upper 'a' sub-zone.

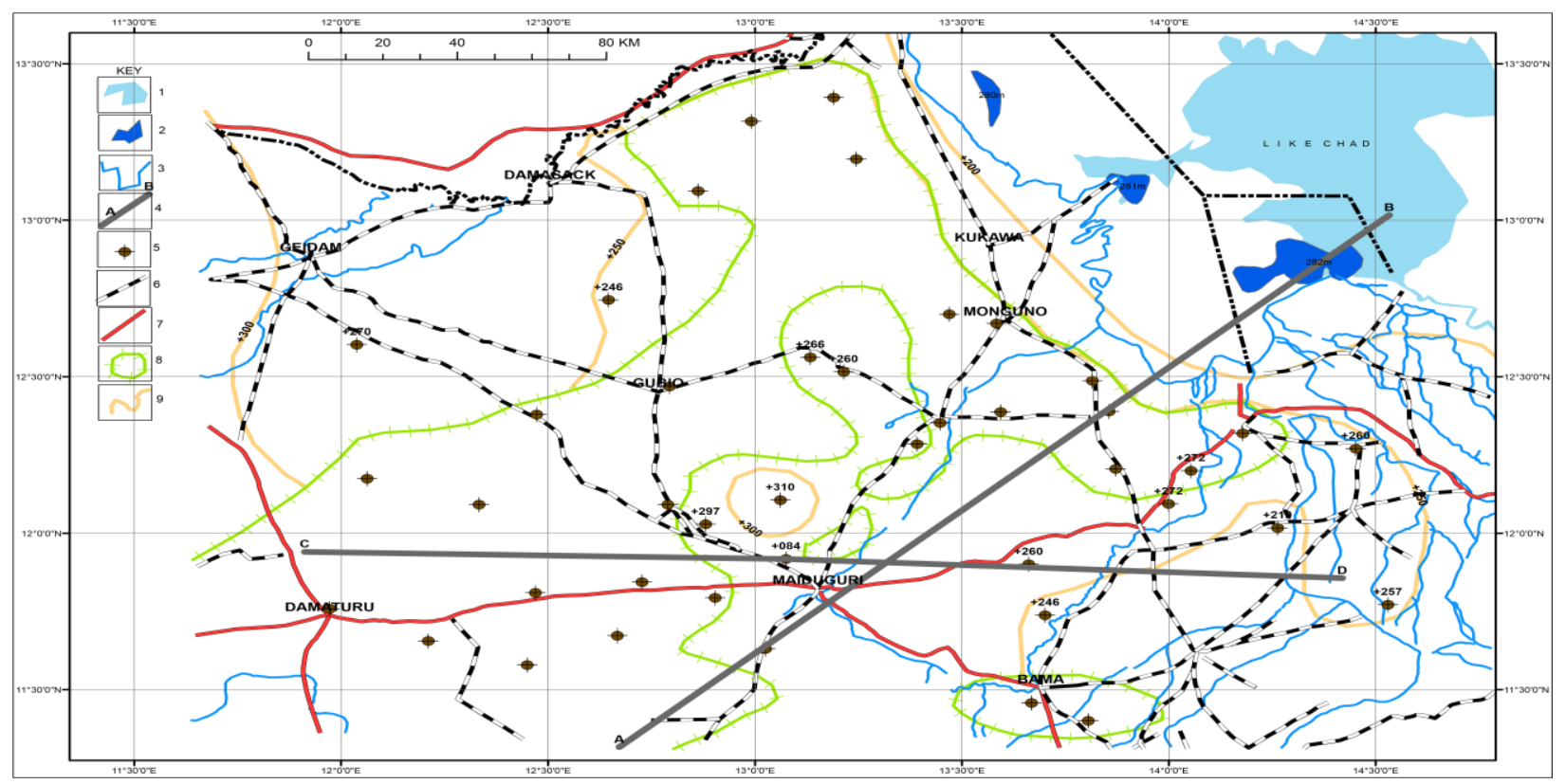

Figure 6: Map of Elevation of bottom of the Upper Aquifer ' b' sub-zones 
Explanation; 1-Lake Chad in 1953 impenetrable surface in white and open water surface in light blue; 2-Remnants of Lake Chad in 2011 in dark blue from Google Earth; 3-Rivers Channels; 4Cross section along $\mathrm{AB}$ and CD; 5-Borehole; 6-Minor Road; 7-Major Road; 8-Boundaries of Hydrogeological windows in the Upper Aquifer 'b' sub-zone; 9-Contours of bottom of Upper 'a' sub-zone.

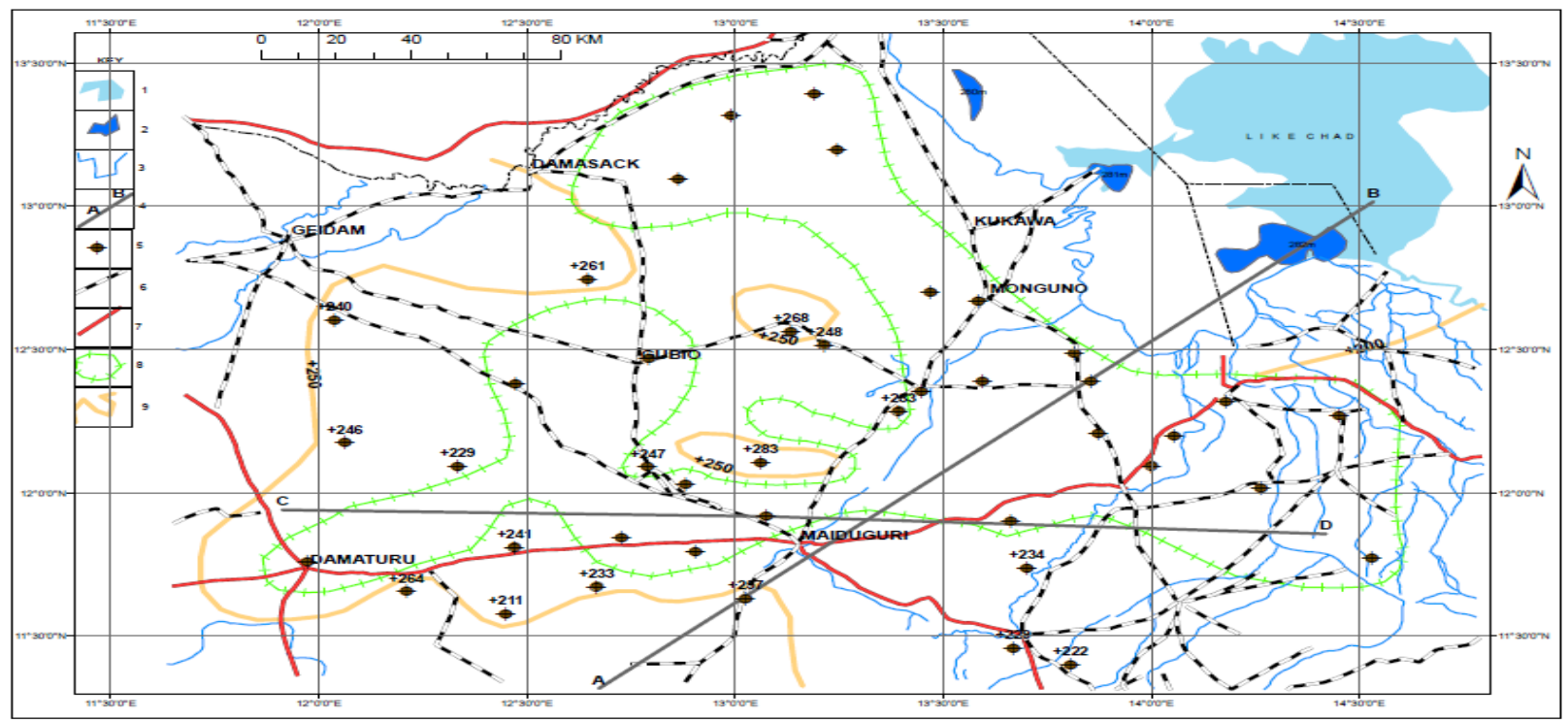

Figure 7: Map of Elevation of Top of the Upper Aquifer ' c' sub-zones

Explanation; 1-Lake Chad in 1953 impenetrable surface in white and open water surface in light blue; 2-Remnants of Lake Chad in 2011 in dark blue from Google Earth; 3-Rivers Channels; 4Cross section along $\mathrm{AB}$ and $\mathrm{CD}$; 5-Borehole; 6-Minor Road; 7-Major Road; 8-Boundaries of Hydrogeological windows in the Upper Aquifer 'c' sub-zone; 9 -Contours of bottom of Upper 'c' sub-zone.

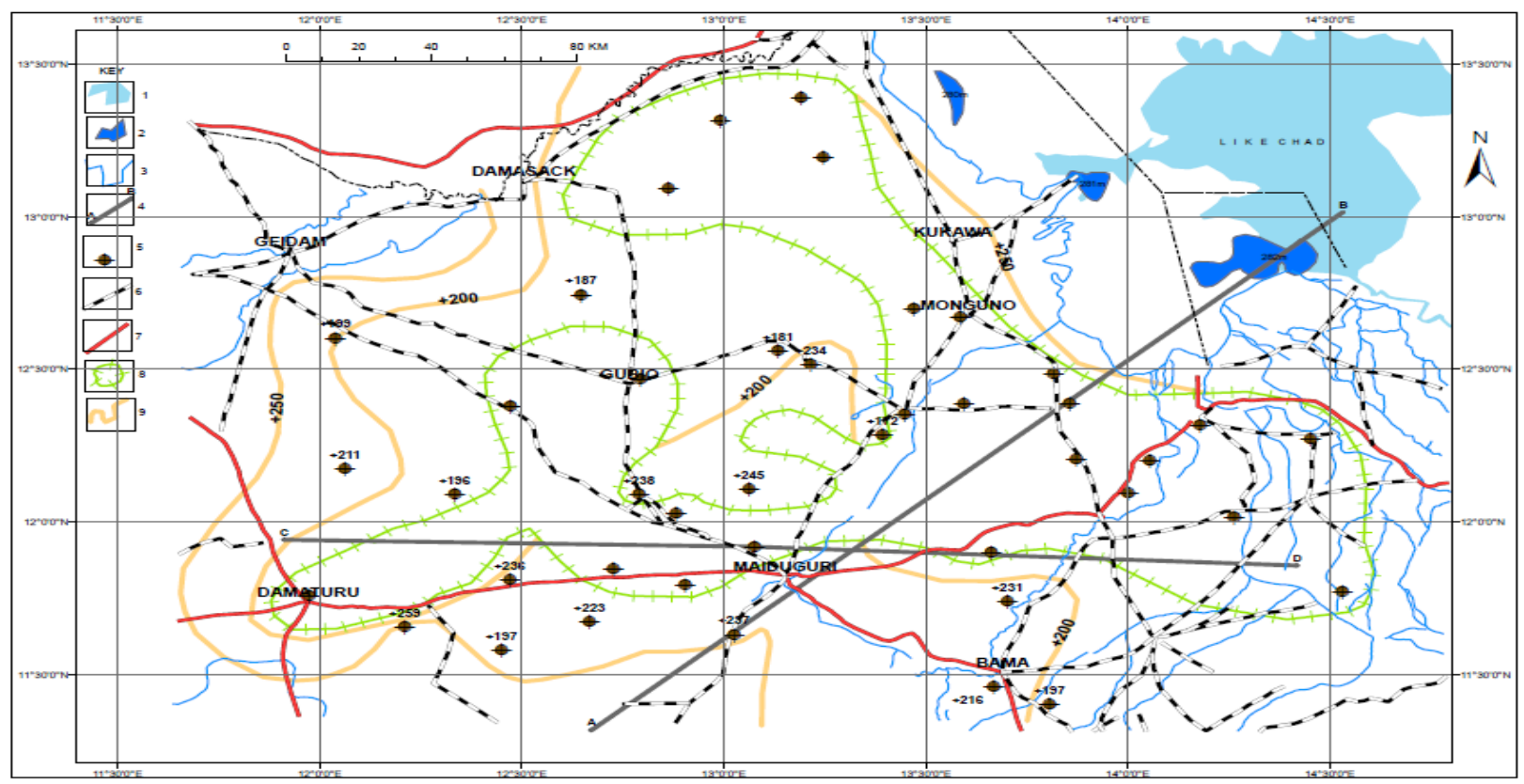

Figure 8: Map of Elevation of bottom of the Upper Aquifer ' c' sub-zones 
Explanation; 1-Lake Chad in 1953 impenetrable surface in white and open water surface in light blue; 2-Remnants of Lake Chad in 2011 in dark blue from Google Earth; 3-Rivers Channels; 4Cross section along $\mathrm{AB}$ and $\mathrm{CD}$; 5-Borehole; 6-Minor Road; 7-Major Road; 8-Boundaries of Hydrogeological windows in the Upper Aquifer 'c' sub-zone; 9 -Contours of bottom of Upper ' $c$ ' sub-zone.

[14] Studied the hydrogeological structures in Chad Formation where the Chad Formation was divided into Upper, Middle and Lower aquifers (Fig. 9). Barber and Jones could not provide detail of the Upper zones and Middle zones into upper a-subzones and lower b-subzones in which the present study was able to provide detailed structural style in the Chad Formation (Fig. 10). Therefore, based on the interpretation of these hydrogeological structures, it can be interpreted that, the middle aquifer receives its recharge directly from the upper zones of the asubzones (Fig. 10) where a-subzones of the upper aquifer is overlying Middle upper zones structurally. This shows that, there is linkage between the Upper a-subzones and the Upper Middle aquifer for the migration of rain water and vice versa. However, looking at this structural map in Fig. 4, it can be deduce that, the hydrogeological windows are mostly located around Maiduguri and its environs.

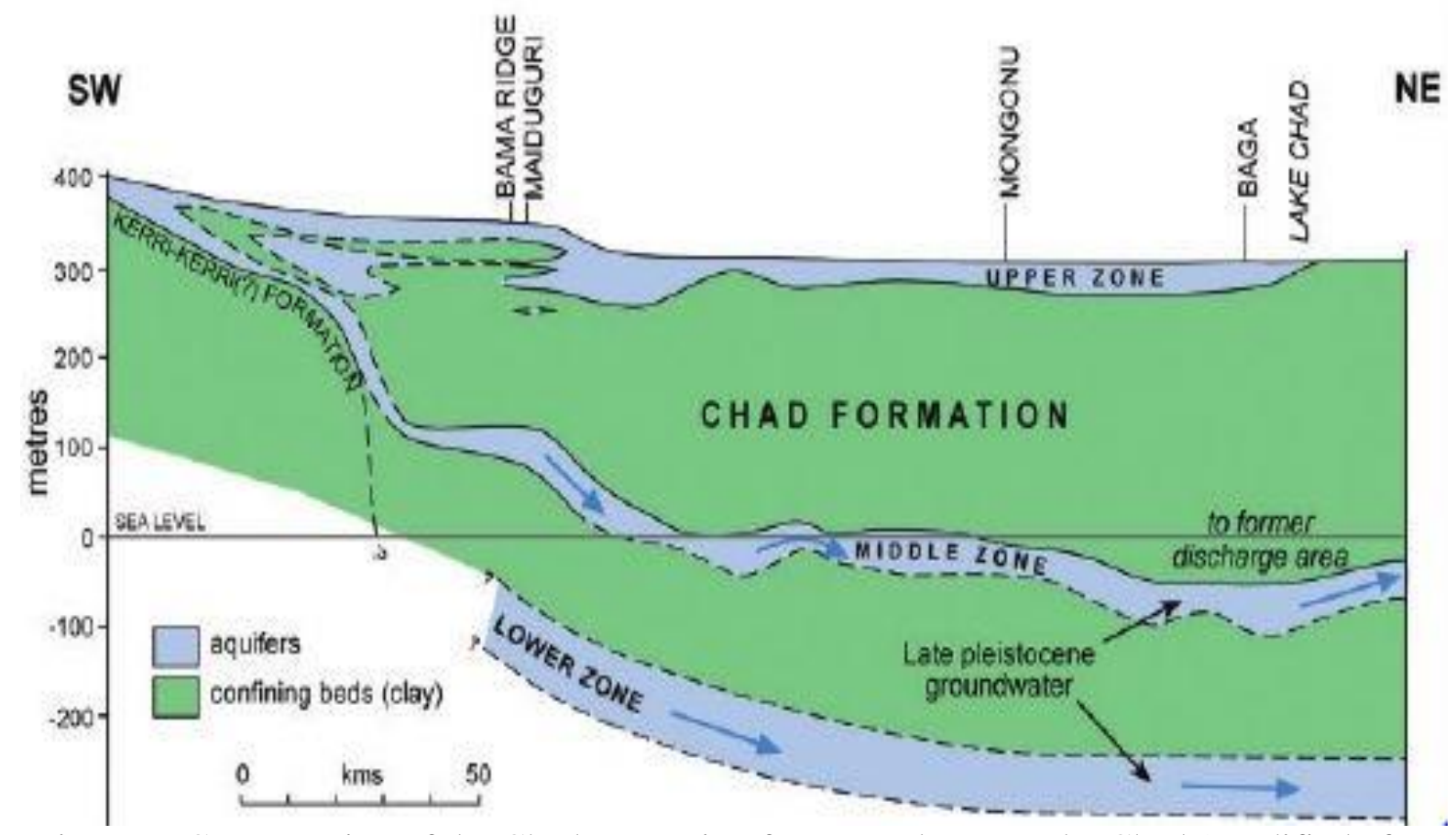

Figure 9: Cross-section of the Chad Formation from Damboa to Lake Chad (Modified after Barber and Jones, 1960) 


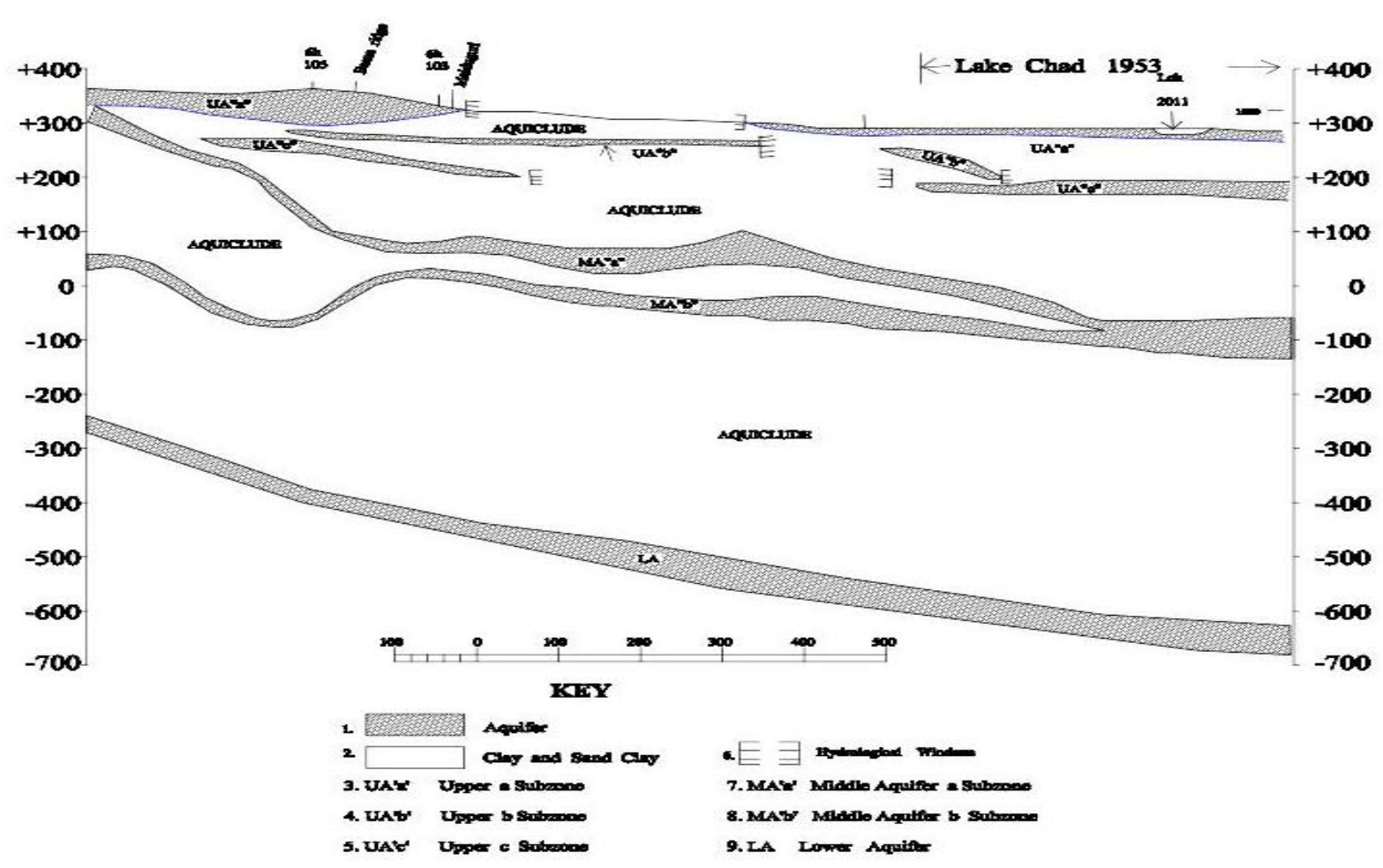

Figure 10: Map of hydrogeological cross-section A-B of Chad Formation showing the three aquifers, (Upper, Middle and Lower Aquifer). The middle Aquifer is separated into a and b subzones.

\section{Conclusion and Recommendation}

From the study, a detail hydrogeological structure in Chad Formation of Chad Basin was study and interpreted from previous drilled borehole logs were three substantive subzones were recognise with minor ones which was not capture in these interpretation. From the study it was clearly seen on the map that, the Upper zones of the Chad Formation consists of hydrogeological windows that is responsible for the migration of rain water from the surface into the underlying bed thereby recharging the aquifer which infiltrated into the middle aquifer through the Upper zones in the middle aquifer and vice versa. However more detail study is needed to evaluate this aquifer and interpret it further and fill the remaining gaps which may exist.

\section{References}

[1] Cratchley, C. R., (1960). 'GEOPHYSICAL SURVEY OF THE SOUTH-WESTERN PART OF THE CHAD BASIN." Paper presented at CCTA Conference on "Geology" February, 1960", Kaduna, Northern Nigeria, (Unpublished). 13p.

[2] Okosun, E. A., (1995). 'REVIEW OF THE GEOLOGY OF BORNU BASIN.' Journal of Mining and Geology 31: 101-126.

[3] Olugbemiro, O. R., (1997). 'HYDROCARBON POTENTIAL, MATURATION AND PALAEOENVIRONMENTS OF THE CRETACEOUS (CENOMANIAN TO SANTONIAN) SERIES IN THE BORNU BASIN.' A Ph.D. Dissertation. Tuebinger Mikropalaeontologische Miteialungen, 14, 138p. 
[4] Cratchley, C. R., Louis P. and Ajakaiye, D. E., (1984). 'GEOPHYSICAL AND GEOLOGICAL EVIDENCE FOR THE BENUE - CHAD BASIN CRETACEOUS RIFT SYSTEM AND ITS TECTONIC IMPLICATIONS.'” Journal of African Earth Sciences, 2(4), 145- 153.

[5] Carter, J. D., Barber, W., Tait, E, A, and Jones, G. P., (1963).' 'THE GEOLOGY OF PARTS OF ADAMAWA, BAUCHI AND BORNO PROVINCES IN NORTH-EASTERN NIGERIAN."' Geological Survey of Nigeria Bulletin No.30: 16-87.

[6] Burke, K. C. and Wilson, T. J., (1972). 'IS THE AFRICAN PLATE STATIONARY?'” Nature, 239, 387-390.

[7] Reyment, R. A., (1980). 'BIOGEOGRAPHY OF THE SAHARAN CRETACEOUS AND PALAEOCENE EPICONTINENTAL TRANSGRESSIONS.' Cretaceous Research, 1, 289-343.

[8] Peters, S. W., (1981). "CENTRAL WEST AFRICAN CRETACEOUS TO TERTIARY BENTHIC FORAMINIFERA AND STRATIGRAPHY.' Palaeontolographica, 179, 1-128.

[9] Binks, R. M. and Fairhead, J. D., (1992). "A PLATE TECTONIC SETTING FOR THE MESOZOIC RIFTS OF WEST AND CENTRAL AFRICA.”' Tectonophysics, 213, 148-149.

[10] Guiraud, R., Binks, R. M., Fairhead, J. D. and Wilson, M., (1992). 'CHRONOLOGY AND GEODYNAMIC SETTING OF CRETACEOUS TO CENOZOIC RIFTING IN WEST AND CENTRAL AFRICA.”' Tectonophysics, 12(213), 234-246.

[11] Genik, G. J. (1992). 'PETROLEUM GEOLOGY OF CRETACEOUS TO TERTIARY RIFT BASINS IN NIGER, CHAD AND CENTRAL AFRICAN REPUBLIC.'” Bulletin of American Association of Petroleum Geologists, 3(77), 1334-1456.

[12] Hamza, H. (1995). 'STRATIGRAPHY, OSTRACOD AND FORAMINIFERAL BIOSTRATIGRAPHY OF KINASA-1 AND KANADI-1 BOREHOLES IN BORNU BASIN: NORTH-EASTERN NIGERIA.'” Unpublished Master's Thesis Department of Geology, Ahmadu Bello University, Zaria Nigeria, 148p.

[13] Consulint, (1979). "HYDROGEOLOGY AND FUTURE EXPLOITATION OF GROUNDWATER FOR MAIDUGURI WATER SUPPLY.’' Consulint International Service Ltd. Maiduguri. Hydrogeological Report 1, 186p.

[14] Barber. W. M. and Jones D. R., 1960. 'GEOLOGY AND HYDROLOGY OF MAIDUGURI BORNO PROVINCE.’' Records of Geological Survey of Nigeria Bulletin 34, 1-36.

*Corresponding author.

E-mail address: bukarmohammed2@yahoo.com 